\title{
SUSTAINABLE RESOURCE GOVERNANCE IN GLOBAL PRODUCTION NETWORKS - CHALLENGES FOR HUMAN GEOGRAPHY
}

\author{
Thomas SchmitT and Christian Schulz \\ With 1 figure and 2 tables \\ Received 27 January $2016 \cdot$ Accepted 25 August 2016
}

\begin{abstract}
Summary: Transnational debates, for instance on the finiteness of fossil resources and their harmful effects on the climate, are often regarded as interdisciplinary challenges in the social and natural sciences. By contrast, in the past two decades, notably in the 2000s, geography appears to have been forgetful of resources. In this paper it is argued that more attention needs to be paid to resource studies in human geography. It starts by comparing existing understandings and definitions of resources in respect of their usefulness as guiding concepts for research. This is followed by an overview of resource-related debates in various subdisciplines of geography. In (environmental) economic geography, the concept of global production networks has proved helpful for the discussion of problems connected with resources. An adaptation of this concept is presented here which can be used to analyse material and energy flows with the aid of social categories (e.g. such as power relations or governance) and to evaluate them in the light of normative categories (e.g. ecological sustainability or environmental justice).
\end{abstract}

Zusammenfassung: Transnationale gesellschaftliche Debatten u.a. um die Endlichkeit fossiler Ressourcen und ihre schädlichen Klimawirkungen werden vielfach als interdisziplinäre Herausforderungen für Sozial- und Naturwissenschaften begriffen. Demgegenüber erscheint die Geographie in den beiden vergangenen Dekaden von einer gewissen Ressourcenvergessenheit gekennzeichnet gewesen zu sein. Der Beitrag möchte für eine verstärkte Hinwendung zur Ressourcenforschung vor allem der Humangeographie plädieren. Hierzu werden zunächst vorliegende Ressourcenverständnisse und -definitionen im Hinblick auf ihre forschungsleitende Relevanz verglichen. Dem schließt sich ein Überblick über die Auseinandersetzung mit Ressourcenfragen in verschiedenen Teildisziplinen der Geographie an. Für eine (umweltorientierte) Wirtschaftsgeographie bietet sich das Konzept der globalen Produktionsnetzwerke für eine Auseinandersetzung mit Ressourcenfragen an. In der hier entwickelten Adaption dient es dazu, Material- und Energieflüsse im Rückgriff auf gesellschaftliche Kategorien (Machtbeziehungen, Governance) zu analysieren und im Hinblick auf normative Kategorien (wie z.B. ökologische Nachhaltigkeit, Umweltgerechtigkeit) zu bewerten.

Keywords: Resources, geographies of resources, global production networks, global value chains, post growth, resource governance

\section{Introduction}

The finiteness of oil reserves and post-fossil energy systems ("peak oil", decarbonization), the consequences of international investment in farmland and forests (including "land grabbing"), the long-term protection of mineral resources (such as precious metal ores, rare earth metals), so-called "resource wars", or the increase of sand mining on beaches all over the world, are all the subject of current debates which have one thing in common: they are interested in the way people interact, economically or politically, with their physical environment, and in negotiations over the importance of natural resources. These issues are often regarded in the light of the emerging discussion of post- growth approaches (see overviews in D'Alisa et al. 2015; SChUlz and BAiley 2014), and the closely associated critical discussion of green economy programmes (Bina 2013; Kenis and Lievens 2015).

However, in the mainstream of human geography it seems that notably over the 2000s resources as a subject of research have sunk into oblivion, especially in the German-speaking countries. There have been very few expert meetings, conferences or publications, even though it is considered as an established research field, for instance from the perspective of man-environment relations (EHLERs 2008). Resource issues have been studied systematically only in certain areas of development geography (including political ecology), or in environment-oriented areas of economic geography. Over 
the last years, the issue of energy transition has attracted attention, from economic, political, social and ecological points of view. But it is justifiable to ask whether human geography is in danger of handing over its frequently claimed "environmental competence" to other disciplines.

This would be regrettable because the interface between human geography and physical geography offers very attractive opportunities for innovative and integrative studies of natural resources (Müller-Mahn and Wardenga 2005). Using the tools of network analysis, a study of how Germanspeaking scholars in geography quote other experts in the same field has shown that geographers involved in the study of environment and resource issues are the main "bridge builders" between subdisciplines (Aufenvenne and STEINBrink 2014). To borrow the words of Matthew Huber, they can contribute to overcoming dichotomous "hyphenated thinking" in the study of nature-society relations (Huber 2010). Cooperative research between the natural and the social sciences is a central desideratum of "sustainability science", which is becoming increasingly significant (HEINRICHS and MiCHELSEN 2014; Heinrichs et al. 2015; JERnECK et al. 2010). In the German-speaking countries, the defenders of transformative science argue in similar terms (Schneidewind and Singer-Brodowski 2014).

In the light of current post-growth debates that are basically devoted to questions of resource governance, we argue in this paper that in human geography more conceptual and empirical research is needed on urgent issues relating to the use of natural resources. The following section gives an overview of the use of the term resources in geography and other social, cultural, economic, natural and applied sciences, with a focus on the physical and material understanding of the term, which is what we are interested in. After this, we will show to what extent four subdiciplines of human geography are currently working on resource issues. We then ask to what degree a resource-governance perspective in geography could provide an integrative approach for more systematic studies of issues relating to social sustainability transitions and their spatial dimensions, and multiscalar interdependencies. Using the example of global production networks (GPN), we discuss ways in which resources can be integrated in a theoretical and conceptual approach that is well established in economic geography. The concluding outlook brings all the arguments together and discusses special challenges.

\section{The variety of notions of resources - a guide through the thicket}

When not only metals, coal reserves or the landscape, but also knowledge, networks or human capital are referred to as resources, it seems that the term resources has a multitude of meanings, not only in different academic disciplines but also in everyday usage (see for instance MeISSNer 2013: 45). We assume that many geographers active today - especially the "Haggett generation" that used Peter Haggett's seminal textbook "Geography: a modern synthesis" as an initiation to their discipline - learned to use the term resources mainly to refer to raw materials, and sometimes to non-material kinds of energy (see HAGGETT 1983). However, in his comprehensive interdisciplinary book which was first published in 1936, Zimmermann (1950: 6) already speaks of a "popular misconception" according to which there is a "strong tendency, easily understandable but nonetheless unfortunate, to identify resources with substances or tangible things." Today, it is quite likely that scholars in the fields of business administration or psychology, upon hearing the term resources, will immediately think of human/social resources as personal skills or social networks rather than things like iron ore, phosphates or coffee beans. Geography, as a meeting point for different natural science and social science disciplines, is a place where these apparently completely different meanings of the term resources come together and this can lead to problems of understanding, for instance in discussions related to the planning of research projects.

The apparent vagueness of the term resource is understandable if we take a look at its etymology. "Resource" is derived from the Old French verb ressourdre, which in turn goes back to Latin resurgere (rise, rise again, recover) (KLUGE 2002; CNRTL 2012). In the Middle Ages and in the modern period ressources in everyday usage in French refers to all possible external or internal means that a person, a state, or an army, for example, can rely on. These include financial means in particular, but also personal character traits; in this usage, not only machines, but also people are among the resources of an army; the resources of a language are the means of expression at its disposal (CNRTL 2012). In the light of this very general usage, it is understandable that in different sciences and paradigms, different understandings of resources have developed, which in turn have been embedded in different, possibly incompatible, concepts and theories. The common 
element in all these uses of the term resource is their reference to the usefulness of whatever it is that is regarded as a resource. Zimmermann (1950: 7) distinguishes his understanding of the term resource from a substantive understanding, which regards the quality of being a resource as a fixed, static property that is inscribed into certain objects. Rather, an object becomes a resource only when it is regarded as useful by a society, a collective or, in certain cases, by an individual: "[T] he word resource is an abstraction reflecting human appraisal and relating to a function or operation" (loc. cit.). This usefulness can be seen in completely different contexts; beyond the production of economic goods or monetary values, it can also lie for example in the satisfaction of aesthetic, therapeutic or spiritual needs (cf. BRIDGE 2009: 1222). In addition to the aspect of usefulness, there is another property that is commonly associated with resources, namely their real, or at least potential, availability to individual or collective actors (see HaggetT, loc. cit.; Bridge 2009: 1217). Thus, minerals on a planet in the Andromeda Nebula (should evidence be found of their existence) would not constitute a resource for humanity, or at most only in an intellectual and symbolic sense.

We would like to offer the following definition for discussion: the term resources should be used to refer to things, assemblages, ensembles, energies, knowledge, or personal or collective properties which:

1. are regarded as useful by individual actors or collectives and which help to supply subjective or collective needs (a subjective or collective and intersubjective value judgement), and/or

2. increase, or at least ensure, the capacity to act of individuals and collectives (a value judgement which can also be made by external observers), and

3. are at least potentially available to individual actors or collectives.

Besides these defining characteristics, many - but not necessarily all - resources show other, non-definining, relevant characteristics which have to be reflected on in any serious geography of resources:

1. The extraction or utilization of "resources" involves work. This applies not only to material resources, such as minerals, but also to immaterial resources, such as knowledge; only in a land of milk and honey would all resources be available with no effort. The work involved in obtaining resources is associated with the development of multiple industries that shape regions and societies, and this nexus has been an important subject of research within human geography (economic geography, but also for instance - landscape studies).
2. Two further non-defining characteristics of many kinds of resources are their scarcity and their finiteness. Scarcity and finiteness in respect of material and energy resources are not only a characteristic of the Earth's natural capital, but also the result of a specific socialization of resources. Experiences of scarcity lead to the development of strategies for protecting resources and to distribution conflicts, but can also trigger strategies for technical or social optimization or substitution of resources. Scarcity is a basic topic in resource economics (see ENDRES and Querner 1993, Ziesemer 2013). Neo-classical concepts regularly talk of the relative scarcity of resources; here, material and immaterial resources are interchangeable in the generation of economic output or growth. By contrast, ecological economists underline the absolute scarcity of natural resources; natural capital and man-made capital cannot be substituted for each other (DALY 1980, BAUMGÄRTNER et al. 2006; GANDENBERGER 2011).

3. However, although things that are referred to as resources are considered as useful, they may in many cases also be problematic, or detrimental, and can thus be described as two-faced. While the work of obtaining resources and their scarcity are central topics in many approaches to the study of resources in the social sciences and economics, the problematic aspects of so-called resources are - at least in some disciplines and approaches - systematically ignored, as for instance in the resource-based view of the firm and preparatory studies (see Wernerfeldt 1984, Penrose 1966, orig. 1959; Liefner and Schätzl 2012: 123). By contrast, the potentially problematic or detrimental character of resources is underlined in research fields such as conflict research or political ecology, since the extraction, distribution or utilization of so-called resources may lead to social conflicts or serious environmental degradation (see WATTS 2004; Flitner and Korf 2012; OssenbrügGE 2007, Tab. 1). Problems with resources occur in essentially three overlapping areas:

(a) The extraction and distribution of resources can trigger acute distribution conflicts, which result ultimately from the perceived scarcity of resources.

(b) The extraction and utilization of resources can have bealth and environmental impacts from the local level (i.e. in the region where a raw material is extracted) to the global level (as in the case of $\mathrm{CO}_{2}$ emissions).

(c) The extraction, but also the utilization, of resources can have socially dysfunctional consequences. A classic example today is the use of risk technologies such as nuclear energy, which can lead 
Tab. 1: Characteristics of resources, related practices, social structures and processes and scientific approaches

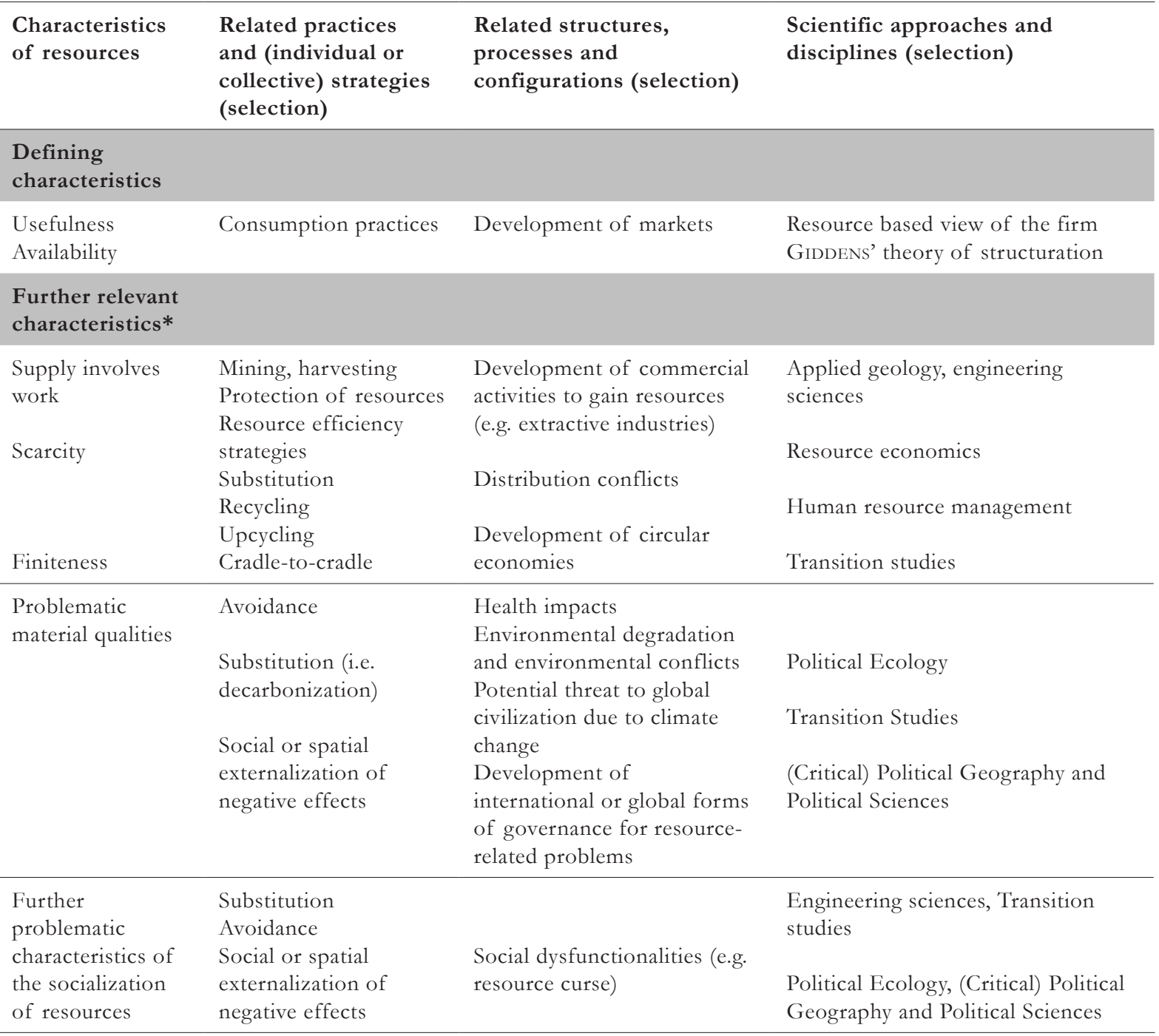

* Non-defining characteristics do not apply to all kinds of resources.

to extensive social restructuring because of the associated risks and the curtailing of civil rights and liberties, as well as opportunities for participation. The so-called "resource curse" (INNIS 1930), or the negative effect on societies of having an abundance of natural resources, is another example.

Some approaches, such as the resource based view of the firm (Wernerfeldt 1984, Penrose 1966, orig. 1959) or GIDDENs' (1984) Theory of Structuration (with its distinction of allocative and authorative resources), have the effect of encouraging a tendency to ignore the problematic nature, or at least the two-facedness, of things referred to as resources. A one-sided relational perspective, which sees only the utility of things or of knowledge, of allocative or authoritative resources, makes it difficult to consider their problematic aspects. Anyone who regards lignite only as a resource, and not (or not primarily) as a climate problem, is positing a one-sided, and maybe highly problematic, abstraction, to borrow the terminlogy of Hegel and Marx (see Belina 2008: 517-8). In studies of material and energy resources, this criticism (which can potentially also apply to non-material resources) can be addresed by not forgetting the things referred to as resources once they have been put to use, for instance in the manufacture of consumer goods. It is important to follow and analyse material and energy flows, and to consider interactions with the natural and social environment at all stages; this is close to 
the material history approach proposed by ReLLER et al. (2013). As we see it, capturing the two-faced, ambivalent quality of resources which can be useful and potentially harmful at the same time, must be a central concern of any resource geography.

\subsection{Recent research on resources in selected subdisciplines of geography}

We have already pointed out that understandings of the term resources and approaches to conducting research on resources vary in different disciplines. In geography there are currently very different ideas about how to design resource geographies (see Bridge 2010, Meissner 2013). In this section we present a review of recent reseach on resources in selected subdisciplines of (human) geography. For reasons of space this will have to be a very brief review. ${ }^{1)}$

Social and cultural geography: In the course of the socialization of human geography and the cultural turn, including the adoption of discursive and post-structuralist approaches in the 1980s and 1990s (with some delay in the German-speaking countries), the discussion of material and energy resources has been neglected in parts of human geography. Social geography has adopted GidDEns' (1984) understanding of resources (see for instance WerLen and Lippuner 2011: 701) and laid emphasis on the symbolic or cultural meanings of material things and ensembles. A counter movement was triggered by the material turn in the social sciences and humanities, and there has been interest in the three-dimensionality of things (Miller 2008). As a result of approaches such as actor-network theory (see Latour 2010), the societal relationships to nature have been conceived in a new light and these approaches have been discussed in resource-related publications (Bridge 2009; Weber 2012). The question of the shaping of resource regimes - for instance on the basis of solar or fossil energy resources - has regularly been the topic of cultural research and reflections (see for example ScHмiтT 2012: 247-8).

\footnotetext{
1) The accounts of the different subdisciplines include input provided by panelists Martin Doevenspeck, Georg Glasze, Britta Klagge and Marit Rosol, as well as by Sybille Bauriedl (audience), during the session entitled "Resource strategies and resource governance for post-growth society" at the Deutscher Kongress für Geographie in Berlin on 3.10.2015. The authors would like to thank the above-named colleagues for their collaboration.
}

Economic geography: At first glance it would seem that in economic geography material and energy resources have played only a marginal role in the past twenty years. The main debates have centred around theory and empirical research in relation to innovative regions and industries, value chains and production networks (with only limited reference to resources; see section 3), or inter-organizational learning and the acquisition of knowledge. Resources have been conceived of as immaterial (for instance in the sense of knowledge, financial capital, patents) rather than material. They have been regarded as assets and not as as problems, and have been understood in a relational rather than a substantive sense (BATHELT and GLÜCKLER 2005).

However, today more attention is being paid to natural resources. In the German-speaking countries, there is evident interest in energy geography (see the activities of the "Arbeitskreis Geographische Energieforschung" - Working Group on Geographical Energy Research within the German Geographical Society - and BRÜCHER 2009). Environmental economic geography has also provided new stimuli in this field (BRAUN et al. 2003). On the international level, there is current research in Progress in Human Geography that is devoted to questions of the sustainability of resources (e.g. BRIDGe 2010, Hobson 2016). Applied Geography also covers regularly resource issues in Economic Geography and dedicated, for instance, a special issue on resource geographies in 2013 (see Reid and Gatrell 2013).

Urban geography: Towns are increasingly being regarded as central arenas for sustainability transitions (BulKeley et al. 2011), especially in respect of energy and climate issues (e.g. potential for rehabilitation of existing buildings, transport planning). Moreover, due to the density and structure of urban populations, towns are regarded as a good breeding ground for social, technical and organizational innovations in the area of alternative resource uses. These include, for instance, new concepts for the production and marketing of foodstuffs (urban gardening/farming, local food cycles) which have grown beyond an ephemeral status in many big cities in industrialized countries (MÜLLER 2012), or the discovery of towns as "raw materials", in the sense of recovering, upcycling and reusing the waste products and materials that occur in large quantities in towns (urban mining). And not least there are resource-saving approaches such as extending the life of products (in repair cafés, for instance), sharing resources (co-working spaces, fab 
labs, car or bike sharing, exchange systems, etc.), or new forms of housing (joint building ventures / cooperatives). For a review of so-called maker communities, see LANGE (2015).

Political geography, political ecology and social ecology: The analysis of social, economic and ecological aspects of resource conflicts, as well as their role in international politics, is an established part of the research agenda of political geography and political ecology (see for example WATTS 2004, DOEVENSPECK 2012, Flitner and Korf 2012; Schneckener et al. 2014, OssenbrüGge 2007). Within political ecology and, for example, in eco-Marxist approaches, "resources ([like] soil, groundwater, timber, fish) form the empirical heart of some of the most exciting theoretically informed research by geographers in recent years" (BAKKER and BRIDGE 2006: 7) - even if such studies do not appear under the label of geography of resources, but claim, for example, to be general investigations into the relationship between man and nature (loc. cit.). In the 1990s and 2000s, political ecology adopted the methods of new institutional economics (NIE), which permit analysis of how different interest groups are able to access resources such as land (Schlager and Ostrom 1992; Schmidt 2013: 21). ${ }^{2}$ A classic research field of political ecology is the study of power relationships between place-based and non-place-based actors (such as transnational companies or international organizations) with regard to control over local resources (BLAIKIE 1985), and their different degrees of exposure to the negative externalities of resource use (Soyez 1985). The spatially and socially unequal distribution of the costs of resource extraction and use are increasingly referred to as a matter of environmental justice (WALKER and BULKELEY 2006; LEHTINEN 2009). The question of the relationship between dualist, dialectical or hybrid conceptions, or the co-production of societies and nature on different scales, is interpreted variously by different authors (see Manson 2008; MCCARTHY 2005; for an overview, see Neumann 2009: 403; on social ecology, see BECKER and JAHN 2006).

Material flow analyses (which are basically compatible with the GPN-approach to resources presented below) and research on the establishment

\footnotetext{
2) Its over-simplified concept of institutions (see for instance KNEER 2008) has been subject to criticism, for example within development geography, and has been increasingly replaced by more complex concepts (e.g. ETzOLD et al. 2012). However, they do not make it easier to forecast the effect of institutions on the way resources are used.
}

of circular economies are currently being conducted in interdisciplinary research institutes like the Wuppertal Institute for Climate, Environment and Energy (see i.e. SCHÜtZ and BringezU 2008; Wood et al. 2015; Geibler et al. 2016; from the field of geography see for instance BRIDGE 2008; ANGEL and Rock 2005).

In view of the different ways the term resources is used, and the conceptual (non-)anchoring and empirical operationalization of resources, founding $a$, or the, new geography of resources would be difficult, if not completely impossible. Rather, we argue that resource finiteness and post-growth debates should play a greater role in contemporary research in human geography. We are particularly interested in the basic patterns and mechanisms of resource governance, and their cross-scale articulation. In accordance with our particular interests, a focus will be placed in the rest of this article on material and energetic resources. This does not mean that we deny the potential relevance of immaterial resources in other contexts, or that we condemn other approaches to material and energy resources.

\section{Resource governance and sustainable social transformation}

In what follows we present a conceptual approach to the geographical study of resource-related patterns and processes of governance before the backdrop of an emerging sustainability transition. This approach does not claim to be completely new, ex nibilo as it were. Rather, it brings together existing, in part well-established, approaches, especially from environmental economic geography (cf. BRAUN et al. 2003). It is intended as a tool for research on resources in the social sciences, but also as an aid for applied sciences that provide political or social consultation services.

Like many other observers in academia, politics or industry, we believe that a sustainable transformation of global society is imperative, and that the provision of energy and the question of resources (which is the more important question in the long term) must be foregrounded (BRIDGE 2009; WBGU 2013). Our approach sets out from sober research in the natural and social sciences, but interprets the results in the light of the explicitly value-oriented goal of sustainable social transformation. In this, it is similar to other analytical frameworks, such as earth systems analysis (cf. Schellnhuber and Wenzel 1998: 
VII). By combining perspectives from the natural and social sciences it opens up opportunities for integrative research in geography (cf. Müller-MAHN and WARDENGA 2005).

The key concept in this approach to resources is that materials are regarded in conjunction with practices relating to their (1) extraction, (2) processing, (3) consumption, and (4) post-consumption treatment, such as dumping or recycling. Steps (1) and (2) can very well be described in terms of value chains or production networks using modified versions of established concepts from economic geography; but from here the analysis relates not to "products" or their "values", but to materials (cf. the "material history approach" in ReLLER and ZEPF 2010). It covers use or consumption and what happens to materials after they have been used in a product. In economic geography, concepts from social sciences relating to the division of power within the chain, or the struggle against competing suppliers on the market, are normally in the foreground of established approaches to value chains and production networks. In the approach we are proposing, the variable to be explained is the way resources are treated during the whole of their "life", the whole "material history", which can be affected by decisions made by individual entrepreneurs, by consumer preferences, by statutory regulations, and also by cultural factors and deeper orientations.

As already suggested, it is possible that established concepts from economic geography can provide a suitable heuristic or empirical framework to spatialize material histories and follow the trajectory of resources, as well as to analyse socio-institutional contexts, influential factors and power mechanisms. The most promising concepts are global commodity or value chains, and global production networks.

\subsection{Global value chains}

Global commodity chains cover the whole production process from extraction of the primary product to delivery of the finished product, and divide this process into separate phases that may be carried out by different companies in different places. Building on the global commodity chain (GCC) approach developed by sociologist Gary Gereffi and his colleagues (GEREFFI and KorZENIEwicz 1994; for a more detailed typology of global value chains (GVC), see GEREFFI et al. 2005), this concept explicitly devotes itself to the power relations and control mechanisms in industries or product-related chains, as well as between different regions of the world (especially North-South relations). These spatial aspects are by their nature in the focus of geographical research. Empirical contributions from economic geography have not only contributed to new differentiations in the understanding and typology of global value chains, but have also for the first time included aspects of environmental governance (Ouma 2010, Bridge 2008, Braun and Bernzen 2014, Dietsche 2011, RePs and BRAUN 2012). Although it has been widely acclaimed and further refined, this approach has two frequently criticized deficits: a) it is not suitable for analysing highly complex network structures and interrelationships, since it rather applies a linear understanding of hierarchically structure chains, and b) it can thematize but not adequately conceptualize institutional contextual conditions in different regions as it considers chain environments rather at a global level. The global production networks approach which was originally developed in economic geography (by a working group at the University of Manchester) addresses these deficits.

\subsection{Global production networks (GPN)}

The GPN approach, which was first presented by Henderson et al. (2002), moves away from the linear idea of a chain and tries to provide a more realistic picture of the organizational (and thus also spatial) complexity of the network structures of global production processes. It also pays more attention to the institutional dimension of production networks, in which not only entrepreneurial and state actors but also civil society groups (trade unions, environment and human rights organizations, etc.) and consumers are included as influential factors. In addition to power aspects, moments of increased value and added value, as well as influences of territorial or relational embeddedness, are also central analytical categories.

Its greater complexity is often seen as the biggest weakness of the GPN approach, because increasing the number of analytical categories reduces the degree of sharpness. This criticism is debatable in that perhaps not analytical sharpness as such is meant, but problems relating to the incomparably greater amount of research that is needed, and the difficulty of presenting the findings (BRAUn and Schulz 2012, 216).

Last year, the debate at the interface between economic geography and political economy on possible adaptations and extensions of the GPN approach has received a decisive impetus: in their widely acclaimed 
article in Economic Geography (Yeung and Coe 2015) and in their book (Coe and Yeung 2015), Henry Wai-Chung Yeung and Neil Coe develop an ambitiuous and dynamic theory of global production networks under the name GPN 2.0. They define GPN as

“(...) an organizational arrangement comprising interconnected economic and noneconomic actors coordinated by a global lead firm and producing goods or services across multiple geographic locations for worldwide markets."

(Yeung and Coe 2015:32)

In particular they claim that non-commercial actors (customers, civil society, the state) play a much more important role in control and decision-making than has hitherto been acknowledged by large parts of the GVC and GPN debates. The authors also plead for the inclusion of uncertainties at the interfaces of GPN as major drivers of the risk-minimizing strategies of companies. They distinguish five kinds of risk (YeUnG and CoE 2015:41): economic risk (market dynamics, exchange rate fluctuations ...), product risk (quality, safety, branding, efficiency considerations ...), regulatory risk (political situation, public-to-private governance, changing standards and norms ...), labour risk (struggles over working conditions and employment practices ...), and environmental risk (natural hazards, human-made disasters ...). These risks also existed in times of Fordian, vertically integrated mass production, but today their effects within GPN have both a greater geographical reach and a higher transmission rate (ibid.: 42). The authors conceptualize four possible risk-minimization strategies: besides intra-firm coordination, inter-firm control, and inter-firm partnership, they pay particular attention to extra-firm bargaining. With their bargaining strategies, both firms and non-commercial actors pursue three inter-related goals: a) market power, b) ownership rights, and c) social and political legitimacy (ibid.: 51). In what follows we will look more closely at these aspects.

Discussions of environment and resource issues in the GPN literature have always tended to regard these issues as negative externalities (including the consequences of strategic relocation to "pollution havens" and the resulting "environmental downgrading" at certain "ends" of the GPN, (MARCONI 2012)). The traditional approach to externalize environmental costs related to resource extraction and processing, initially seen as a risk minimization strategy, increasingly turns into an economic risk as environmental (and social) standards rise globally, or, maybe more frequently, as ecologically harmful practices are scandalized by NGOs and the media. The
GVC literature is more explicit in respect of changes in product design and production processes that contribute to the "upgrading" of GVC as a result of pressure by external stakeholders, including customers (De Marchi et al. 2013 a and 2013b; Rissgaard et al. 2010). However, such changes tend to be interpreted as a reactive process in which firms recognize and use the pressure to adapt as an opportunity to gain pioneer advantages.

If one considers global production networks not only as a heuristic concept for studying global production and value-added processes, but primarily as an organizational pattern and mode of governance that dominates in many industries (approx. 80\% of international trade is generated by multinational companies and their GPN, Yeung and Coe 2015: 30), this opens up an interesting change of perspective in respect of resource governance. The following approaches can help to explain what proactive potentials GPN could valorize in connection with questions of resource finiteness and improved resource governance. We adopt an explicitly normative position and deliberately reverse discussed logics and causal relations to illustrate our argument:

1. Global hegemonies in GPN: Many authors attest to obvious power asymmetries within international network structures and speak of the global influence of particular (industrial) countries and leading multinational corporations: "(h)egemonic powers have the capacity to produce highly differentiated resource geographies" (BRIDGE 2009, 1231). This can be seen not only in the disproportional use of natural resources from countries in the Global South and the peripheries of the Global North since the beginning of industrialization, but also in the current search for, and long-term securing of, resources (land, ores ...) through transcontinental agreements (including "land grabbing"). Conversely, with the systemic understanding of GPN it would be possible to explain how powerful GPN actors are able to establish more sustainable standards in resource use, independently of whether their motives are intrinsic or extrinsic (due to exogenous social pressure).

2. Interface between regions and firms: The (controversially) discussed "strategic coupling" of the interests of GPN companies and the regions where they are located (e.g. investor-friendly social and environment policies) and their mutual path dependencies (MACKINNON 2012) also implies that changing social conditions in a GPN region will affect firms and their institutional environment on a global scale. For example, ethically or ecologically motivated changes in consumer 
behaviour in high-volume sales markets or target groups can be just as influential as national norms and regulations (like the EU product standards for electrical equipment which are perceived as a "green wall" in Asian export countries).

3. The relationship between GPN actors and end consumers, whose lifestyles can have an important influence on sales patterns and thus on product development and investment decisions:"In addition to economic factors such as price and quality, consumers are now better informed and take into account other noneconomic considerations such as ethical and social responsibility and environmental impact in their consumption decisions." (Yeung and Coe 2015:38). The increasing role of "fair trade" and similar labels, and the related adaptation pressure on local producers, buyers, and the retailing sector may impact the entire production network.

4. External regulations/governance structures and GPN: The conceptual literature on GPN refers explecitely to external political regulations or governance forms - both at a national and an international/global level - shaping and influencing GPN (HENDERson et al. 2002). Standards of WTO, international conventions, regulations of tree trade zones or the EU shape the exchange of materials and (semi-finished) goods within GPN and the governance structures of GPN themselves, and they have also a potential influence on material resource flows. According to well established critique, environmental aspects are not adequately considered for instance within the WTO regulations (see BRAND 2005). Despite their obvious influence, it has to be questioned whether international regulation has an adequate (i.e. sustainability oriented) impact on resource uses and material flows within GPN.

Through the interconnectedness of corporate strategies, government regulations and socio-cultural factors with functional and material aspects of global production networks, the GPN approach provides a very interesting analytical framework for the study of resource governance. Especially the level of "strategic coupling" between elements or dynamics of GPN and regional development pathways offers a promising perspective for further conceptualizing the link between business decisions, physical resource flows and the socio-institutional environment. It also allows to grasp both notions of embeddedness discussed in economic geography: While the relational embeddedness is recognized as a core principle structuring the GPN's internal governance patterns, territorial emebeddedness seems to be underconceptualized on only weakly covered by the notion of regional coupling.

Fig. 1 is an expansion of usual flow diagrams showing the processes involved in GPN. In contrast to common GVC and GPN approaches, we extend the focus also on the usage and the post-usage phase of goods (dumping, deposition, recycling, ...), as many of the problematic aspects of materials become crucial at that moment.

This is achieved, firstly, through the identification of physico-technical categories. Terms and indicators referring to the extraction, transformation and use of resources represent the variables to be explained, and are fundamental to the description of the energy and material aspects of resource-related processes, such as the efficiency of a specific use of resources. The socio-economic and socio-cultural analysis and normative assessment, for instance of the sustainability of resource strategies, are based on the results in these categories. Questions relating for instance to the (harmful) biological effects or effects on ecosystems of the resources themselves, but also of their extraction, processing and disposal processes, are included here.

Secondly, social, economic and cultural categories are introduced. The corresponding terms and indicators relate, for instance, to the practices and strategies of actors, the allocation of power and profits within production networks, their institutional structure and their governance, for example by external regulatory interventions. On a second level, they relate to the effective models, the underlying discourses and thus specific cultural embeddings of production and resource strategies, consumer preferences and specific political attempts to exercise influence. These categories must also be able to map transformations in production, consumption and post-use patterns, due for instance to new technological or economic developments.

Thirdly, specific space-related categories refer to the spatial embedment of physico-technical and social processes, and the generally unequal spatial consequences of resource flows and resource strategies. They can be linked to normative questions, such as inter-regional equity.

Fourthly, and finally, normative categories, terms and corresponding indicators from the natural and social sciences take up questions of the sustainability of resource use and the justice of resource flows (with reference for instance to the allocation of profits within production networks, or unequal ecological burdens in different regions). These categories can be linked to 


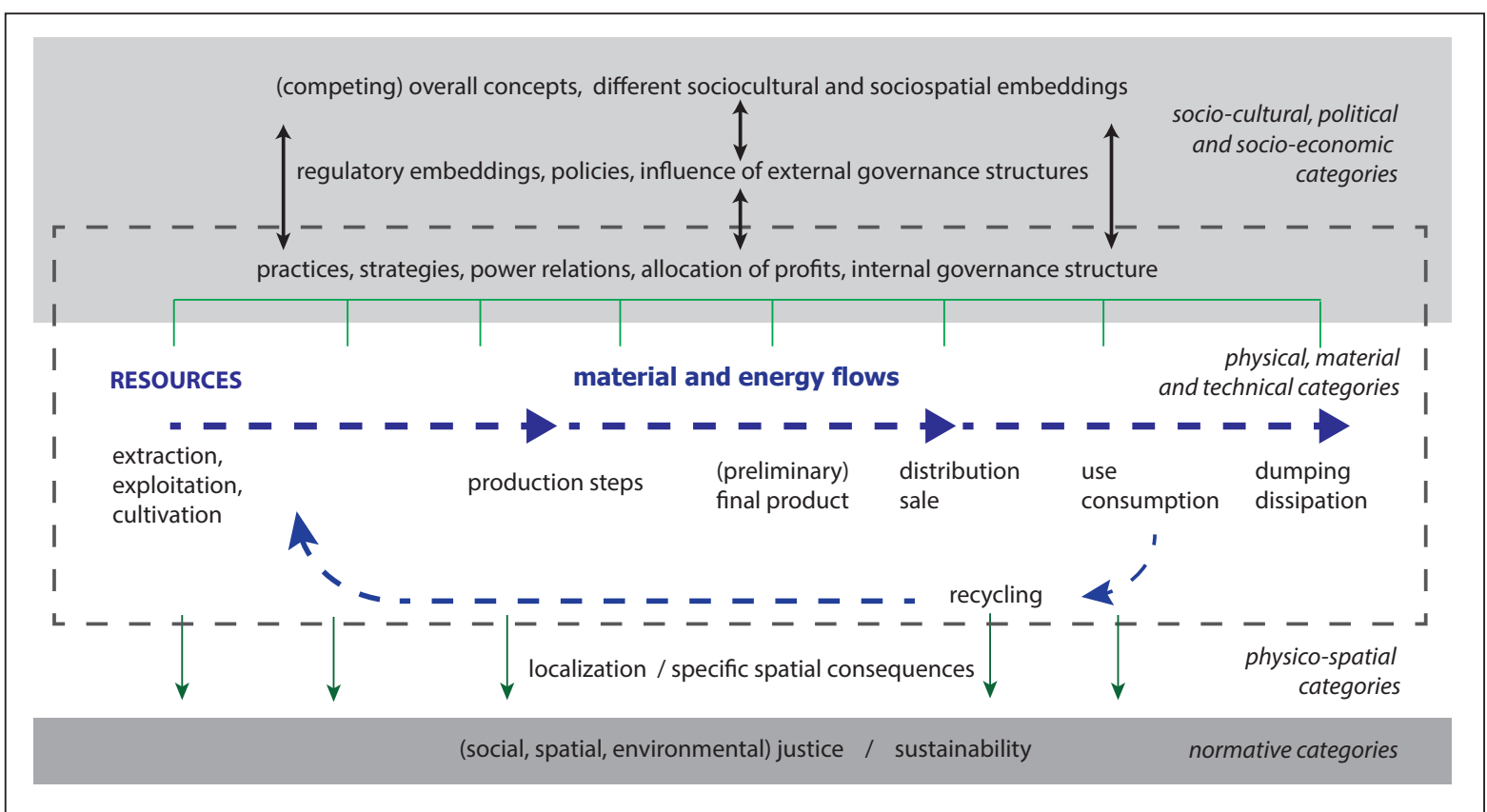

Fig. 1: General framework for the analysis of resource-based production networks, for use in human geography. Designed by the authors on the basis of Reller and Zepf (2010); Braun and Schulz (2012, 215), Brücher (2009, 26) and SChMitT (2012, 251); the linear representation of material and energy flows is a deliberate simplification for the purpose of better visualization, and does not do justice to the real complexities of GPN.

discussions on "environmental" and "social" justice. Such normative terms are increasingly being taken up by social and economic actors, as seen in the much-discussed case of the "Fairphone" (see for example MCEACHran 2013).

\section{Geographies of resources and the post- growth debate}

The GPN heuristic presented here, and adapted to suit the study of resouces, makes it possible to understand how resource flows are changed (in the best case optimized) in existing production networks, and what the driving forces are behind these changes, such as decisions made by key actors or external regulatory interventions. However, a comprehensive sustainability transition will need more than simple optimization strategies within existing production networks; there will have to be more fundamental changes, including the possibility of substitution in the case of many products or services. The German Advisory Council for Global Change, for example, propagates in its 2011 "flagship report", that a Great Transformation would encompass "profound changes to infrastructures, production processes, regulation systems and lifestyles, and extends to a new kind of interaction between politics, society, science and the economy" (WBGU 2011:1). The council pleads for no less than "a new global social contract for a low-carbon and sustainable global economic system" (ibid.).

For this reason the external or environmental dimension of GPN is especially important. We are interested not only in how social and cultural processes of change, and related shifts in respect of consumer preferences, values and regulatory instruments, can influence resource governance within GPN, but also how a shift in values within firms can lead to new GPN structures and patterns of governance.

Good examples are the clothing industry and the agri-food industry, two sectors which have become more and more globalized over the past few decades, and which have received much public attention and criticism. In the case of the clothing industry, precarious or even scandalous working conditions in low-wage countries in the Global South have been condemned, and this has led to changes in the biggest firms involved (voluntary commitments, fair trade labels, CSR initiatives, etc.) (ROBERTs 2003). In the agri-food sector, discussion is focused mainly on ecological aspects and problems connected with geographi- 
cal origin (such as transport-related energy costs), but social aspects (including the current effects of the falling milk prices in the EU) also play a role and contribute to the debate, for instance in respect of the re-regionalization of value chains (BERNZEN 2014). Both problem areas of climate change, with the need for a global decorbonization, and the finiteness of raw materials might only be effectively managed by relatively strong global governance mechanisms which necessarily transform or reconstruct, in the long run, all (global) production networks.

At the heart of every debate on post growth or degrowth are issues relating to resources (finiteness, fair allocation, protection, management ...). Conversely, resource studies in (economic) geography must inevitably take into account prevalent models and development mottos and their alternatives, independently of whether the current post-growth approaches - which are to some extent ideological - are accepted or not. If degrowth or post growth is understood, following Latouche (2010) or Jackson (2009), as an explicit renunciation of material growth paradigms and thus as a fundamental change in business principles (social responsibility, social business) and individual values (sufficiency; for an overview, see SCHNEIDEWInd and Zahrnt 2014), the resulting changes within GPN can only be considered from a decidedly co-evolutionary perspective. In other words, analytical concepts and methods must be able to explain the interplay between social transformation processes and reconfigurations in the organization of production.

Spatial differentiations in the analysis are crucial and have to take into account both the diversity of social contextual conditions and particular regional environments. It appears to be helpful to consider systematically all four analytical categories shown in Fig. 1. Existing approaches in economic geography which adopt a co-evolutionary perspective (e.g. evolutionary economic geography, transition studies) provide valuable contributions to an understanding of the contextual conditions that affect basic innovation processes (disruptive changes), but are not designed to cope with the complexity of the interdependencies described above. Firstly, they are based on a narrow understanding of innovation, and focus almost exclusively on technological change (Coenen et al. 2015). Secondly, most empirical studies are sectorally oriented in the sense that they are devoted to particular indus- tries (such as the wind turbine industry) or policy areas (such as energy policy). And thirdly, even when explicitly based on a relational understanding of space, the analysis is usually restricted to the national or regional context, while global and cross-scale interdependencies are neglected (Affolderbach and Schulz 2016). Social diversity and heterogeneous contextual conditions on a global scale must be grasped as being subject to dynamic change, which is an additional challenge for research on resources.

\section{Synthesis and outlook}

In this paper we have tried to do justice to past research on resources in human geography, but also to point out important deficits. At the same time starting from a systematic categorization of different meanings of the term resources - we have shown where there are obvious potentials for a more intensive study of resources in geography. This seems to be all the more important as current debates on climate change and resource finiteness show the political and social urgency of such research. Some substantial studies (especially on resource-related conflicts in countries of the Global South, see DitTRICH 2015) have been published in different subdisciplines of geography. However, they nearly always regard resource issues as regional problems with global causes (such as resource policies in countries of the Global North that are hostile to the environment and to human rights). Even if they do succeed in identifying some important interrelationships und impact chains, a more holistic approach to international resource governance is required. It must be designed with cross-sector and cross-scale factors in mind and must be capable of mapping the economic, political and social dimensions of resource-related problems.

Using the example of GPN, we have shown that such an analytical and conceptual (and thus also methodological) approach is extremely complex, not least because the different groups of actors involved are interdependent in many different ways. It is therefore of especial importance to ask which impulses for fundamental changes in the production system go out from which groups (see above), and which reactions and adaptations they trigger in other groups, or in other regions of the world. The GPN heuristic on coping with uncertainties provides a set of conceptual instruments not only for identifying processes of change, but also for examining their causes and their effects more systematically. 
From an analytical perspective, the extended GPN concept with its strategic couplings and its multiscalar understanding of contexts shows some similarities with perspectives applied in the so called Transition Studies (or Social Studies of Technology). The probably most prominent concept from this school, the multi-level perspective/MLP (GEELs 2002), conceptualizes the co-evolution of societal and technical change as an interplay between an overarching (exogenous) sociotechnical landscape, patchworks of established (and dominant) socio-technical regimes as well as so-called niches where radical innovations can develop and potentially lead to adjustments in the dominant regimes. The latter may then influence the socio-technical landscape. At the same time, the socio-technical landscape (e.g. through fundamental shifts of global climate or energy policies) can trigger niche innovations and changes at the regime level. As such, transitions do not only result from path breaking innovations at the niche level (bottom-up), but are at least influenced by changes of the general socio-technical environment, opening windows of opportunities via regulation, research policies, tax systems etc. (top-down). This compelling MLP heuristic, initially focussing on the explanation of radical technological change in given industries and (mostly) national economies, is increasingly applied to other contexts and scales, e.g. the field of urban energy policies (ROHRACHER and SPÄTH 2014). A series of scholars seek to better conceptualize the spatial articulations of transitions towards sustainability (see overviews in COENEN et al. 2012, HANSEN and COENEN 2015, Murphy 2015).

Tab. 2.: Possible corresponding elements of GVC/GPN approaches and transition studies/social studies of technology for the study of resource-related production regimes

\begin{tabular}{|c|c|c|c|c|}
\hline $\begin{array}{l}\text { Vocabulary used in } \\
\text { the GPN approach } \\
\text { as analytical } \\
\text { categories/ } \\
\text { dimensions }\end{array}$ & $\begin{array}{l}\text { Vocabulary used } \\
\text { in Transition } \\
\text { Studies to describe } \\
\text { factors stabilizing } \\
\text { regimes }\end{array}$ & $\begin{array}{l}\text { Vocabulary } \\
\text { used in } \\
\text { Transition } \\
\text { Studies to } \\
\text { describe } \\
\text { regime } \\
\text { transition }\end{array}$ & $\begin{array}{l}\text { Vocabulary } \\
\text { used to describe } \\
\text { exogenous risks } \\
\text { for GPN }\end{array}$ & Role of resources \\
\hline $\begin{array}{l}\text { Network/chain (with } \\
\text { material flows and } \\
\text { resources as inputs) }\end{array}$ & $\begin{array}{l}\text { Sociotechnical } \\
\text { regime }\end{array}$ & $\begin{array}{l}\text { Technological } \\
\text { niche }\end{array}$ & Product risk & $\begin{array}{l}\text { Explicitly addressed } \\
\text { in material aspects } \\
\text { of chains, regimes } \\
\text { and technological } \\
\text { choices }\end{array}$ \\
\hline $\begin{array}{l}\text { Structure/ } \\
\text { production network }\end{array}$ & $\begin{array}{l}\text { Infrastructure } \\
\text { Technology }\end{array}$ & $\begin{array}{l}\text { Technological } \\
\text { substitution } \\
\text { (de-/re-) } \\
\text { alignment }\end{array}$ & $\begin{array}{l}\text { Product risk } \\
\text { Labour risk }\end{array}$ & $\begin{array}{l}\text { Implicitly addressed } \\
\text { (e.g. in relation with } \\
\text { material substitution } \\
\text { and resource } \\
\text { intensity) }\end{array}$ \\
\hline Value & $\begin{array}{l}\text { Techno-scientific } \\
\text { knowledge } \\
\text { Markets }\end{array}$ & & $\begin{array}{l}\text { Economic risk } \\
\text { Environmental } \\
\text { risk }\end{array}$ & $\begin{array}{l}\text { Explicitly addressed } \\
\text { in relation to } \\
\text { environmental risks }\end{array}$ \\
\hline Power, Governance & $\begin{array}{l}\text { Regime } \\
\text { Sectoral policy } \\
\text { Strategic games } \\
\text { Co-ordination }\end{array}$ & $\begin{array}{l}\text { Pressure from } \\
\text { sociotechnical } \\
\text { landscape }\end{array}$ & $\begin{array}{l}\text { Regulatory risk } \\
\text { Labour risk }\end{array}$ & $\begin{array}{l}\text { Implicitly addressed } \\
\text { (e.g. landscape } \\
\text { pressure related to } \\
\text { resource issues) }\end{array}$ \\
\hline Embeddedness & $\begin{array}{l}\text { Industrial networks } \\
\text { User Practices } \\
\text { Cultural and } \\
\text { symbolic meaning } \\
\text { Sociotechnical } \\
\text { landscape }\end{array}$ & $\begin{array}{l}\text { Pressure from } \\
\text { sociotechnical } \\
\text { landscape } \\
\text { New visions } \\
\text { (within niches) }\end{array}$ & $\begin{array}{l}\text { Regulatory risk } \\
\text { Environmental } \\
\text { risk }\end{array}$ & $\begin{array}{l}\text { Implicitly addressed } \\
\text { in relation with } \\
\text { stakeholder pressure, } \\
\text { consumer behaviour, } \\
\text { lifestyles etc. }\end{array}$ \\
\hline
\end{tabular}


A link to the GPN approach could be drawn if one understands the current functioning of a production network as an established/predominant regime, embedded into a broader context (landscape). The latter encompasses both the global business environment of the respective industry as well as regional and local contexts ("regional couplings") where changes in policies, values, consumer preferences and stakeholder pressure may impact established routines and structures.

Table 2 shows some overlap in the notions of the respective vocabulary used in the GPN and the Transition Studies Literature. The factors inducing changes in the regime (right column) are framed in a similar manner as the five types of exogeneous risks illustrated by Yeung and CoE (2015, see above). Without necessarily using the concept of nicheness in its mere technological sense, these factors and adaptation pressures often lack a further operationalisation in current GPN research. The MLP heuristic might provide a complementary heuristic to better describe and interpret the emergence of a new resource governance and its geographies. It might also allow to make prospective recommendations on the basis of the results. It only remains to hope that the topic of resources will continue to stimulate conceptual debates on the GPN approach.

\section{Acknowledgements}

This research has not received any specific funding. We would like to thank two anonymous reviewers for their valuable comments. All errors remain our own.

\section{References}

Affolderbach, J. and Schulz, C. (2016): Mobile transitions? Green building innovations in urban contexts. In: Urban Studies 53 (9), 1942-1957. https://doi. org/10.1177/0042098015583784

Angel, D. and Rock, M. (2005): Global standards and the environmental performance of industry. In: Environment and Planning A 37, 1903-1918. https://doi. org/10.1068/a3788

Aufenvenne, P. and Steinbrink, M. (2014): Säulen der Einheit: Zur Stellung integrativer Autorinnen in der deutschsprachigen Geographie. In: Geographische Revue 16 (2), 23-33.

BAkker, K. and Bridge, G. (2006): Material worlds? Resource geographies and the 'matter of nature'. In: Pro- gress in Human Geography 30 (1), 5-27. https://doi. org/10.1191/0309132506ph588oa

Bathelt, H. and GlüCKleR, J. (2005): Resources in economic geography: from substantive concepts towards a relational perspective. In: Environment and Planning A 37, 1545-1563. https://doi.org/10.1068/a37109

Baumgärtner, S.; Becker, C.; FAber, M. and Manstetten, R. (2006): Relative and absolute scarcity of nature: assessing the roles of economics and ecology for biodiversity conservation. In: Ecological Economics 59 (4), 487498. https://doi.org/10.1016/j.ecolecon.2005.11.012

Becker, E. and Jahn, T. (eds.) (2006): Soziale Ökologie. Frankfurt am Main.

Bernzen, A. (2014): Reassessing supplier reputation in international trade coordination - a German and Australian perspective of global organic food networks. In: Die Erde 145 (3): 162-174. https://doi.org/10.12854/ erde-145-15

BelinA, B. (2008): Geographische Ideologieproduktion - Kritik der Geographie als Geographie. In: ACME. An International E-Journal for Critical Geographies 7 (3), 510-537.

BINA, O. (2013): The green economy and sustainable development: an uneasy balance? Environment and Planning C. In: Government and Policy 31, 1023-1047. https:// doi.org/10.1068/c1310j

BlatKIE, P. (1985): The political economy of soil erosion in developing countries. New York, London.

Brand, U. (2005): Gegen-Hegemonie. Perspektiven globalisierungskritischer Strategien. Hamburg.

Braun, B.; Schulz, C. and Soyez, D. (2003): Konzepte und Leitthemen einer ökologischen Modernisierung der Wirtschaftsgeographie. In: Zeitschrift für Wirtschaftsgeographie 47 (3-4), 231-248. https://doi. org/10.1515/zfw.2003.0019

Braun, B. and Bernzen, A. (2014): Conventions in crossborder trade coordination: the case of organic food imports to Germany and Australia. In: Environment and Planning A 46 (5), 1244-1262. https://doi. org/10.1068/a46275

Braun, B. and Schulz, C. (2012): Wirtschaftsgeographie. Stuttgart.

BRIDGE, G. (2008): Global production networks and the extractivesector: governing resource-based development. In: Journal of Economic Geography (8), 389-419. https://doi.org/10.1093/jeg/lbn009

BRIDGE, G. (2009): Material worlds: natural resources, resource geography and the material economy. In: Geography Compass 3 (3), 1217-1244. https://doi. org/10.1111/j.1749-8198.2009.00233.x

BRIDGE, G. (2010): Resource geographies 1: making carbon economies, old and new. In: Progress in $\mathrm{Hu}-$ man Geography 35 (6), 820-834. https://doi. org/10.1177/0309132510385524 
BRÜCHER, W. (2009): Energiegeographie: Wechselwirkung zwischen Ressourcen, Raum und Politik. Stuttgart.

Bulkeley, H.; Castán, B. V.; Hodson, M. and Marvin, S. (eds.) (2011): Cities and low carbon transitions. London, New York.

CNRTL: Centre National de Ressources Textuelles et Lexicales (2012): Ressource: Définition de Ressource. http:/ / www.cnrtl.fr/definition/ressource (Date: 17.8.2015).

Coe, N. M. and WaI-Chung Yeung, H. (2015): Global production networks: theorizing economic development in an interconnected world. Oxford.

Coenen, L.; Benneworth, P. and Truffer, B. (2012). Toward a spatial perspective on sustainability transitions. In: Research Policy 41 (6), 968-979. https:/ / doi.org/10.1016/j. respol.2012.02.014

Coenen, L.; Hansen, T. and Rekers, J. V. (2015): Innovation policy for grand challenges. An economic geography perspective. In: Geography Compass 9 (9), 483-496. https://doi.org/10.1111/gec3.12231

D’Alisa, G.; Demaria, F. and Kaldis, G. (eds.) (2015): Degrowth: a vocabulary for a new era. London.

Daly, H. (1980). Economics, ecology, ethics: essay toward a steady-state economy. San Francisco.

De Marchi, V.; Di Maria, E. and Micelli, S. (2013a): Environmental strategies, upgrading and competitive advantage in global value chains. In: Business Strategy \& the Environment 22 (1), 62-72. https://doi.org/10.1002/ bse. 1738

De Marchi, V.; Di Maria, E. and Ponte, S. (2013b): The greening of global value chains: insights from the furniture industry. In: Competition \& Change 17 (4), 299-318. https://doi.org/10.1179/1024529413Z.00000000040

DieTsChe, C. (2011): Umweltgovernance in globalen Wertschöpfungsketten. Umweltschutz und Qualitätssicherung im Handel mit tropischen Garnelen und Ledererzeugnissen. Wirtschaftsgeographie 48. Münster.

DitTrich, C. (2015): Ressourcen- und Umweltkonflikte in Entwicklungs- und Schwellenländern. In: Geographische Rundschau 47 (12), 4-10.

Doevenspeck, M. (2012): „Konfliktmineralien“: Rohstoffhandel und bewaffnete Konflikte im Ostkongo. In: Geographische Rundschau 64 (2), 12-19.

Ehlers, E. (2008): Das Anthropozän: Die Erde im Zeitalter des Menschen. Darmstadt.

Endres, A. and Querner, I. (1993): Die Ökonomie natürlicher Ressourcen. Darmstadt.

ETZOLD, B.; JÜLICH, S.; KeCK, M.; SAKDAPOLRAK, P.; SCHMITT, T. and Zimmer, A. (2012): Doing institutions. A dialectic reading of institutions and social practices and its relevance for development geography. In: Erdkunde 66 (3), 185-195. https://doi.org/10.3112/erdkunde.2012.03.01

Flitner, M. and Korf, B. (2012): Kriege der Zukunft = Klimakriege? In: Geographische Rundschau 64 (2), 46-48.
Gandenberger, C. (2011): Das Konzept der absoluten Knappheit und seine Implikationen für das Stoffstrommanagement. http://www.isi.fraunhofer.de/isi-wAssets/docs/n/de/publikationen/04_Gandenberger_ neu.pdf (Date: 04.11.2015)

GeELs, F. (2002): Understanding the dynamics of technological transitions: a co-evolutionary and socio-technical analysis. Enschede.

Geibler, J. v.; Cordaro, F.; Kennedy, K.; Lettenmeier, M. and Roche, B. (2016): Integrating resource efficiency in business strategies. A mixed-method approach for environmental life cycle assessment in the single-serve coffee value chain. In: Journal of cleaner production 115, 62-74. https://doi.org/10.1016/j.jclepro.2015.12.052

Gereffi, G. and Korzeniewicz, M. (eds.) (1994): Commodity Chains and Global Development. Westport.

Gereffi, G.; Humphrey, J. and Sturgeon, T. J. (2005): The governance of global value chains. In: Review of International Political Economy 12 (1), 78-104. https://doi. org/10.1080/09692290500049805

GidDEns, A. (1984): The constitution of society. Outline of the theory of structuration. Cambridge.

Haggetr, P. (1983): Geographie. Eine moderne Synthese. New York.

Hansen, T. and Coenen, L. (2015): The geography of sustainability transitions: review, synthesis and reflections on an emergent research field. In: Environmental Innovation and Societal Transitions 17, 92-109. https://doi. org/10.1016/j.eist.2014.11.001

Heinrichs, H. and Michelsen, G. (eds.) (2014): Nachhaltigkeitswissenschaften. Berlin, New York.

Heinrichs, H.; Martens, P. and Michelsen, G. (eds.) (2015): Sustainability science - an introduction. Berlin, New York.

Henderson, J.; Dicken, P.; Hess, M.; Coe, N. and WaiChung Yeung, H. (2002): Global production networks and the analysis of economic development. In: Review of International Political Economy 9 (3), 436-464. https://doi.org/10.1080/09692290210150842

Hobson, K. (2016): Closing the loop or squaring the circle? Locating generative spaces for the circular economy. In: Progress in Human Geography 40 (1), 88-104. https:/ / doi.org/10.1177/0309132514566342

Huber, M. (2010): Hyphenated geographies: the deindustrialization of nature-society geography. In: The Geographical Review 100 (1), 74-89. https://doi. org/10.1111/j.1931-0846.2010.00007.x

InNIS, H. (1930): The fur trade in Canada. New Haven.

JACKSON, T. (2009): Prosperity without growth: economics for a finite planet. London.

Jerneck, A.; Olsson, L.; Ness, B.; Anderberg, S.; Baier, M.; Clark, E.; Hickler, T.; Hornborg, A.; Kronsell, A.; Lövbrand, E. and Persson, J. (2011): Structuring sus- 
tainability science. In: Sustainability Science 6 (1), 69-82. https://doi.org/10.1007/s11625-010-0117-x

Kenis, A and Lievens, M (2015): The limits of the green economy: from re-inventing capitalism to re-politizizing the present. London.

KLuge, F. (2002): Etymologisches Wörterbuch der deutschen Sprache, 24. Auflage. Berlin.

KneER, G. (2008): Institutionen/Organisationen. Über die Paradoxie des Organisierens. In: Moebius, S. and ReckWITZ, A. (eds.): Poststrukturalistische Sozialwissenschaften. Frankfurt a.M., 124-140.

Lange, B. (2015): Fablabs und Hackerspaces. Die Rolle der Maker-Community für eine nachhaltige Wirtschaft. In: Ökologisches Wirtschaften 30, 8-9.

Latouche, S. (2010): Degrowth. In: Journal of Cleaner Production 18 (6), 519-522. https://doi.org/10.1016/j. jclepro.2010.02.003

Latour, B. (2010): Eine neue Soziologie für eine neue Gesellschaft. Einführung in die Akteur-Netzwerk-Theorie. Frankfurt a. M.

Lehtinen, A.-A (2009): Environmental justice. In: R. KiтcHIN and N. Thrift (eds.): International encyclopedia of human geography. Oxford, 535-539.

Liefner, I. and SCHÄtzL, L. (2012): Theorien der Wirtschaftsgeographie. Stuttgart.

MacKinnon, D. (2012): Beyond strategic coupling: reassessing the firm-region nexus in global production networks. In: Journal of Economic Geography 12 (1), 227-245. https://doi.org/10.1093/jeg/lbr009

Manson, S. (2008): Does scale exist? An epistemological scale continuum for complex human-environment systems. In: Geoforum 39, 776-788. https://doi. org/10.1016/j.geoforum.2006.09.010

MARCONI, D. (2012): Environmental regulation and revealed comparative advantages in Europe: Is China a pollution haven? In: Review of International Economics 20 (3), 616-635. https://doi.org/10.1111/j.14679396.2012.01042.x

McCarthy, J. (2005): Scale, sovereignty, and strategy in environmental governance. In: Antipode 37, 731-753. https:/ / doi.org/10.1111/j.0066-4812.2005.00523.x

McEachran, R. (2013): Could Fairphone help clean up supply chains in the smartphone market? In: The Guardian, 19.9.2013. http://www.theguardian.com/sustainablebusiness/fairphone-supply-chain-smartphone-market (Date: 01.12.2015)

Meissner, S. (2013): Ressourcengeographie. Eine Einführung. In: Reller, A.; Marschall, L.; Meissner, S. and SснміDт, C. (eds): Ressourcenstrategien. Darmstadt, 38-64.

Miller, D. (2008): Material culture. In: BenNetT, T. and Frow, J. (eds.): The Sage handbook of cultural analysis. London, 271-290. https://doi.org/10.4135/9781848608443.n14
Müller, C. (2012): Practicing commons in community gardens: urban gardening as a corrective for homo economicus. In: Bollier, D. and Helfrich, S. (eds): The wealth of the commons. A world beyond market and state. Amherst, 219-224.

Müller-Mahn, D. and Wardenga, U. (eds.) (2005): Möglichkeiten und Grenzen integrativer Forschungsansätze in Physischer und Humangeographie. Forum IfL 2. Leipzig.

Murphy, J. T. (2015): Human geography and socio-technical transition studies: promising intersections. In: Environmental Innovation and Societal Transitions 17, 73-91. https://doi.org/10.1016/j.eist.2015.03.002

Neumann, R. P. (2009): Political ecology: theorizing scale. In: Progress in Human Geography 33 (3), 398-406. https://doi.org/10.1177/0309132508096353

OssenbrüGge, J. (2007): Ressourcenkonflikte ohne Ende? Zur Politischen Ökonomie afrikanischer Gewaltökonomien. In: Zeitschrift für Wirtschaftsgeographie 51 (1), 150-162.

Ouma, S. (2010): Global standards, local realities: private agrifood governance and the restructuring of the Kenyan horticulture industry. In: Economic Geography 86(2), 197-222. https://doi.org/10.1111/j.19448287.2009.01065.x

Penrose, E. T. (1966, orig. 1959): The theory of the growth of the firm. Oxford.

Reid, N. and Gatrell, J. (2013): Resource geographies \& economic development: understanding place-based industries in a global economy. In: Applied Geography 45, 363-364. https://doi.org/10.1016/j.apgeog.2013.09.021

Reller, A. and Zepf, V. (2010): Supply chain scheme. In: Fraunhofer-Projektgruppe für Wertstoffkreisläufe und Ressourcenstrategie (o. J.): Ressourcenstrategien. http:// www.iwks. fraunhofer.de/de/geschaeftsbereiche/ressourcenstrategien.html (Date: 25.4.2014)

Reller, A.; Marschall, L.; Meissner, S. and Schmidt, C. (eds.) (2013): Ressourcenstrategien. Eine Einführung in den nachhaltigen Umgang mit Rohstoffen. Darmstadt.

Reps, N. and Braun, B. (2012): Going Green. Ökologische Aufwertungsprozesse und Koordinationsstrukturen in den Wertschöpfungsketten der indischen Kraftfahrzeugindustrie. In: Zeitschrift für Wirtschaftsgeographie 56 (4), 226-243. https://doi.org/10.1515/zfw.2012.0016

Ritsgaard, L.; Bolwig, S.; Ponte, S.; Du Toit, A.; Halberg, V. and Matose, F. (2010): Integrating poverty and environmental concerns into value-chain analysis: a strategic framework and practical guide. In: Development Policy Review 28 (2), 195-216. https://doi.org/10.1111/ j.1467-7679.2010.00481.x

Rohracher, H. and SpÄTH, P. (2014): The interplay of urban energy policy and socio-technical transitions: 
the eco-cities of Graz and Freiburg in retrospect. In: Urban Studies 51 (7), 1415-1431. https://doi. org/10.1177/0042098013500360

RoberTS, S. (2003): Supply chain specific? Understanding the patchy success of ethical sourcing initiatives. In: Journal of Business Ethics 44 (2-3), 159-170.

Schellnhuber, H. J. and Wenzel, V. (eds.) (1998): Earth system analysis. Integrating science for sustainability. Berlin.

Schlager, E. and Ostrom, E. (1992): Property rights regimes and natural resources: a conceptual analysis. In: Land Economics 68 (3), 249-262. https://doi.org/https://doi.org/10.2307/3146375

Schmidt, M. (2013): Mensch und Umwelt in Kirgistan. Politische Ökologie im postkolonialen und postsozialistischen Kontext. Erdkundliches Wissen 153. Stuttgart.

Schmiтt, T. (2012): Postfordistische Energiepolitiken? Das Desertec-Konzept als Szenario zur Restrukturierung der Energieversorgung in der EUMENA-Region. In: Zeitschrift für Wirtschaftsgeographie 56 (4), 244-263.

SCHNeCKener, U.; Scheliha, A. v.; LienkAmp, A. and KLAGGE, B. (eds.) (2014): Wettstreit um Ressourcen. Konflikte um Klima, Wasser und Boden. München.

Schneidewind, U. and Singer-Brodowski, M. (2014): Transformative Wissenschaft: Klimawandel im deutschen Wissenschafts- und Hochschulsystem. Marburg.

SCHNEIDEWInd, U. and Zahrnt, A. (2014): The politics of sufficiency. Making it easier to live the good life. München.

Schulz, C. and Bailey, I. (2014): The green economy and post-growth regimes: opportunities and challenges for economic geography. In: Geografiska Annaler Series B - Human Geography 96 (3), 277-291. https://doi. org/10.1111/geob.12051

Schütz, H. and BRINGEZu, S. (2008): Ressourcenverbrauch von Deutschland - aktuelle Kennzahlen und Begriffsbestimmungen. Umweltbundesamt. Forschungsberichte 02-08. Dessau.

Soyez, D. (1985): Ressourcenverknappung und Konflikt. Entstehung und Raumwirksamkeit mit Beispielen aus dem mittelschwedischen Industriegebiet. Arbeiten aus dem Geographischen Institut der Universität des Saarlandes 35. Saarbrücken.

Walker, G. P. and Bulkeley, H. (2006): Geographies of environmental justice. In: Geoforum 37 (5), 655-659. https://doi.org/10.1016/j.geoforum.2005.12.002

Watts, M. (2004): Resource curse? Governmentality, oil and power in the Niger Delta, Nigeria. In: Geopolitics 9 (1), 50-80. https://doi.org/10.1080/14650040412331307832

WBGU (2013): Wissenschaftlicher Beirat der Bundesregierung Globale Umweltveränderungen (WBGU): Hauptgutachten Welt im Wandel. Gesellschaftsvertrag für eine Große Transformation. 2. Aufl. Berlin.
Weber, H. (2012): Urbanisierung und Umwelt: Ein Plädoyer für den Blick auf Materialitäten, Ressourcen und urbane ,Metabolismen'. In: Informationen zur modernen Stadtgeschichte 2, 28-35.

Werlen, B. and Lippuner, R. (2011): Sozialgeographie. In: Gebhardt, H.; Glaser, R.; Radtke, U. and Reuber, P. (eds.): Geographie - Physische Geographie und $\mathrm{Hu}-$ mangeographie. Heidelberg, 686-712.

WernerfeldT, B. (1984): A resource based of the firm. In: Strategic Management Journal 5, 171-180.

WoOD, R. ET AL. (2015): Global sustainability accounting. developing EXIOBASE for multi-regional footprint analysis. In: Sustainability 7 (1), 138-163. https://doi. org/10.3390/su7010138

Yeung, H. W. and Coe, N. (2015): Toward a dynamic theory of global production networks. In: Economic eography 91 (1), 29-58. https://doi.org/10.1111/ecge.12063

Ziesemer, T. (2013): Wie viel Kuchen für wie lange? Eine ressourcenökonomische Perspektive auf den Abbau erschöpflicher Ressourcen. In: Reller, A.; MARSCHALl, L.; Meissner, S. and Schmidt, C. (eds.): Ressourcenstrategien. Darmstadt, 89-104.

Zimmermann, E. W. (1950): World resources and industries. Revised Edition. New York.

Authors:

PD Dr. Thomas Schmitt Institute of Geography University of Erlangen-Nuremberg Wetterkreuz 15 91058 Erlangen Germany thomas.schmitt@fau.de

Prof. Dr. Christian Schulz Institute of Geography and Spatial Planning University of Luxembourg Maison des Sciences Humaines

11, Porte des Sciences 4366 Esch/Alzette

Luxembourg christian.schulz@uni.lu 